\title{
Curating Cartographies of Knowledge: Reading Institutional Study Abroad Portfolio as Text
}

\section{Julie M. Ficarra \\ Syracuse University}

The overarching assumption within popular approaches to global learning is that it takes place either in classrooms at home or in the case of study abroad, in experiential learning environments overseas. Policies and programs are carefully crafted to respond to particular institutional goals and objectives towards internationalization. These objectives have increasingly aligned with broader neoliberal reforms within universities that focus on the student as a global consumer (Bolen, 2001). This places those responsible for designing and implementing international programs in a precarious position, often having to straddle a widening divide between critical educator and travel agent. While efforts are made to create programs that allow students to engage cross-culturally, internationally, and in meaningful ways, there also exists immense pressure to do so in the shortest amount of time and for the least amount of money. As more study abroad offices become selffunded, or financially self-sustaining, this often means prioritizing programs that are the most attractive to the student 'consumer' as opposed to the student 'academic'.

This competition between study abroad as academic endeavor and study abroad as business is illustrated in the bifurcation of the study abroad literature. One strand of the literature focuses squarely on the student experience, which includes questions of students' motivation for studying abroad and/or what they have gained from the experience. These studies often emphasize students' personal growth and development, their increased cross-cultural competence and understanding, as well as their changing conception of global citizenship (Cabrera, 2010; Clarke, 2004; Milstein, 2005). The second category of study abroad literature focuses on 'best practices' and policies for the implementation of study abroad programs. This includes work on student and faculty recruitment strategies, program design, monitoring and evaluation tools, safety and risk management as well as re-entry programming for newly returned study abroad participants (Childress, 2009; Crossman \& Clarke, 2009; Brockington et. al, 2005; Mitchell, 2006).

What is largely missing from both sets of literature is an exploration of the global learning that takes place before a study abroad program begins; what are students learning about the world and their place within it when they visit a study abroad office website, thumb through a promotional pamphlet or attend a program recruitment event? To my knowledge there has been no explicit acknowledgement in the study abroad literature of the hidden curriculum that presents itself through what I refer to as institutional study abroad portfolios (ISAPs), that is, the compilation of study abroad programs that a university promotes to its students that take place in particular locations focusing on specific academic disciplines. In this paper I will argue that in looking at ISAPs as a unit of analysis we can uncover political complexity that is often obfuscated both by more macro level policy analysis (i.e. internationalization strategy) as well as more micro-level program evaluation. 
The ways in which international visions and missions are actually taken up at the program development level play an important role in guiding students through the process of situating themselves in the global system in a way that is either transformative or serves to reify privileged neo-imperial positions (Tikly, 2004). I believe that this 'situating' process can and often does take place long before students commit to a study abroad program. For this reason, methods of cultural representation, and the 'common sense' geographical and disciplinary pairings ubiquitous in international education deserve much more careful attention.

Using three post-secondary institutions in the U.S. to illustrate these ideas, the paper will begin with an exploration of meta-narratives in study abroad programming, namely the ways in which study abroad marketing plays a role in shaping representations of both the study abroad experience itself as well as the foreign 'Other'. This will serve as a foundation for reading the institutional study abroad portfolio (ISAP) as text and identifying the potential for hidden curriculum in how study abroad is framed within institutions' international mission and vision statements, as well as in how study abroad programs are geographically categorized. I will use Alexander \& Mohanty's (2010) concept of 'cartographies of knowledge' to explore the politics of knowledge legitimization that is embedded in ISAPs as well as to problematize the disciplinary and experiential hierarchies that result. Finally, the paper will conclude with a discussion of future directions for the analysis of ISAPs toward a more critical, anti-imperial, international education policy orientation.

\section{Meta-Narrative \& Representation in Study Abroad Programs}

A term popularized by social theorist Jean-François Lyotard, 'meta-narrative' refers to "a global or totalizing cultural narrative schema which orders and explains knowledge and experience" (Stephens \& McCallum, 2013, p. 6). Lyotard argued that modernity is defined by a suspicion of meta-narratives and a proclivity towards more localized narratives that illustrate the full range of human experiences. Study abroad could be understood as answering the post-modern call for increased engagement with localized narratives, as it should push students to think beyond the limits of their own environment and preconceived notions to grapple with varied international perspectives and lived experiences. However, the design of individual faculty-led programs is what often authors these narratives. The inclusion and exclusion of particular activities, site visits, background readings, and local partners all shape the localized narrative that U.S. students come to consume.

While the nature of the localized narratives that are crafted through study abroad program design is worth extensive exploration, this paper is interested in how study abroad destinations are broadly represented and particularly the way that a portfolio of different study abroad program offerings across geographic locations and disciplines presented as a whole, orders and explains knowledge and experience and how this meta-narrative can run contrary to stated goals of study abroad programs. In her chapter entitled "Study Abroad Marketing and the Privatization of Global Citizenship" Talya Zemach-Bersin (2008) discusses the relationship between the type of commercial discourse used to promote study abroad programs and the vocabulary students use to describe their overseas experiences. She is critical of the ways in which study abroad is often framed "within the language of discovery" which "grants the experience a status of myth-like proportions and glory with roots in frequently violent and destructive histories" (p. 308) and makes several suggestions for a more critical and academic discourse around study abroad marketing. 
In a similar effort, Caton and Almeida Santos (2009) analyze the promotional material used by study abroad provider Semester at Sea, a program that features multiple study abroad sites on one "voyage". They found that despite the organization's stated mission of promoting cross cultural understanding and global citizenship, the program still (re)produces hegemonic depictions of nonWesterners. Sarah Bishop (2013) uses Martin Heidegger's concept of “enframing” to explore digital representations of the study abroad experience through the analysis of alumni testimonials on the study abroad websites of the three U.S. institutions that sent the most students abroad during the $2009 / 2010$ academic year. She uses textual and discourse analysis to unpack themes and frames that emerge within promotional material across different programs at these three institutions and suggests that "heightened awareness of the implicit distance between academic sojourners and the idealized mediated rhetoric they encounter during their academic sojourning process as a starting place to reconceptualize both the potential of study abroad programs overall and the ways in which they are promoted to students" (p. 410).

\section{Reading Institutional Study Abroad Portfolio (ISAP) as Text: A 'Hidden Curriculum'}

Critical pedagogues have written widely on the concept of the hidden curriculum (Apple, 1982; Giroux, 1983), which Jane Martin (1984) defines as "lessons which are learned but are not openly intended". The original concept refers primarily to the ways in which the structure of public schools in the U.S. reinforce, instead of transcend, societal power relations. In this way, it is a useful framework for unpacking power relations, privileges, and hidden hierarchies that exist within institutional structures that are openly intended to promote mutual understanding and global subjectivities. While most internationalization policy takes a specific ideological stance, it is those implicit structures and epistemologies which claim no politics that we should be most critically attentive to.

For the purposes of grounding this analysis I have chosen three of the top twenty U.S. Study Abroad Sending Institutions, measured either by the number of students that they send abroad or by the percentage of the total institutional student population who study abroad (IIE, Open Doors, 2012). These institutions are not intended to be representative of all study abroad sending institutions across the U.S. but rather of a diverse range of institutions (in terms of size, geography, and public/private status) that value study abroad as evidenced by the number (or percentage) of their students that have chosen to participate in a study abroad program. The first is a large state university system in the South Eastern U.S. with a student population of about 32,000 - which I will refer to as South East University (SEU); the second is a medium sized Jesuit Catholic research university in New England with a student population of about 14,000 - which I will call New England University (NEU); and the last is a small liberal arts college in the Mid-Atlantic with a student population of about 2,000 - which I will call Mid-Atlantic University (MAU). While all of the data I have accessed is public, found on the study abroad website of each school, I felt that referring to them by name would be beside the point. The idea here is not to point fingers at particular institutions but rather to challenge all international educators to think critically about their own institutions as well as the broader national trends around internationalization policy and representation. 


\section{Vision \& Mission As 'Open Intentions'}

Morphew and Hartley in their 2006 study of institutional mission statements exclaim "They're everywhere! They're everywhere!" and indeed those of us positioned within U.S. colleges and universities know firsthand the ubiquity of the apparently all important and all powerful mission statement. However, Morphew and Hartley ask whether these ever-evolving documents are "strategic expressions of institutional distinctiveness" or "organizational window dressings that are normative necessities" (p. 459), they find that it seems to be a bit of both. Yet, "recognition of international dimension in institutional mission statements, planning, and policy documents" is still considered an important guiding element of an institutional internationalization strategy (Knight, 2004) and students continue to value international opportunities when it comes to choosing a college (American Council on Education, 2008).

With this in mind, the analysis of NEU, SEU, and MAU begins with a survey of their mission and vision language found either on the study abroad website itself or on the institution's home page. In scrolling through the 'About Us' section of the SEU study abroad website, there is no stated mission or goals of study abroad communicated directly to students but rather an overview of what study abroad is and what it can do for them and the university.

"Study Abroad is the principal and arguably the quickest means through which students can begin the journey of becoming global citizens. It is also one of the most effective means of internationalizing the university... By taking part in an international academic experience, students will gain dynamic skills that are vital in today's global environment, while at the same time leading the way towards helping [SEU] achieve one of its strategic initiatives, that of internationalizing our campus." (emphasis added)

As Zemach-Bersin (2008) and Bolen (2001) have suggested, the emphasis on the speed with which one can 'become a global citizen' reflects broader trends in consumer culture which privileges the quick and easy. There is no indication of the university's approach to study abroad or how it defines 'global citizen' or 'dynamic skills'. There is also a noticeable emphasis placed on contributing to the university's mission of internationalization, which supports theories that suggest that the offering of international opportunities has become an increasingly important marketing and recruitment tool.

Along this vein, MAU's institutional homepage makes reference to its high study abroad ranking and centers International Education in its institutional mission. It states:

"Education Without Boundaries: [MAU] is a selective, private, coed, liberal arts college dedicated to providing a multidisciplinary, international education, and it is the first college in the nation to make study abroad an undergraduate degree requirement. Empowered by rigorous academics, a close-knit, residential campus community, and hands-on experience in the world, $[\mathrm{MAU}]$ students graduate as true global citizens." (emphasis added)

This statement explicitly positions the world as 'out there', students must go abroad to gain 'hands-on experience in the world'. In a poignant critique of this type of rhetoric Lisa Taylor (2011) writes: "A global citizenship education of "bringing the world into our classroom; forgets that our classrooms are always already in the world, entangled economically, discursively and affectively" (p.177). Also potentially problematic is the conflation of required study abroad with 'true global citizenship' - which assumes that going abroad has transformed students' sense of global 
subjectivity and citizenship and that they have indeed engaged meaningfully with the overseas community that hosted them.

Finally, the NEU Office of International Program Mission reads:

"In accordance with [NEU's] tradition and values, the mission of the Office of International Programs (OIP) is to prepare students for an increasingly interdependent and culturally

diverse world. The office's aim is for students to engage in intellectually rigorous and personally transformative experiences that play an integral role in the teaching and learning that take place on campus." (emphasis added)

Much like SEU, NEU places institutional goals (traditions, values, teaching and learning) at the center of their international mission. Along with MAU, NEU stresses both the academic and intellectual rigor of their international programs as well as the interdependence of the 'culturally diverse world'.

\section{Program Length and 'Type'}

While study abroad programs come in many shapes and sizes, two primary variants are 'program length', meaning the amount of time students spend abroad and 'program type', meaning how the program is implemented and by whom. According to the 2013 Institute of International Education (IIE) Open Doors Report, only 3.2\% of students who study abroad participate in a 'long term program' defined as an academic or calendar year, and while $37.9 \%$ of students choose a midlength program (one semester) the majority of students, $58.9 \%$, study abroad on a summer program lasting eight weeks or less. These trends in students' preferred length of stay abroad impact the 'types' of programs that are created and administered by institutions. For example, shorter programs tend to be led by institutional faculty and involve a group of U.S. students exploring a number of sites in a particular country around an academic question, theme, or service objective. Longer programs tend to be housed either at an institution's 'university center' abroad where students take courses from U.S. or international faculty, with or without local students, or at a college or university abroad. The latter model can either be structured as a 'direct exchange' where a bilateral exchange of students takes place between the U.S. and non-U.S. institution, as a 'direct enroll' meaning the U.S. student enrolls directly at the institution and takes courses alongside local students, or an alternative model in-between.

A comprehensive analysis of an ISAP would include an exploration of all institutional study abroad programs, reading across program length and type, and might address questions regarding how the institutional choice to offer programs of particular lengths and type communicates certain international education priorities to students. However, for the purposes of this paper, I will look specifically at short-term summer programs as they are the most widely engaged model across U.S. study abroad sending institutions and account for the largest percentage of study abroad participation. These will include faculty-led, 'in-house' programs, as well as 'provider programs', programs that are designed, managed and implemented through a third-party provider, an organization (which can be for-profit or not-for-profit) that has been pre-approved by each institution. Also, because short term programs are the most popular and often very closely tied to institutional faculty, they tend to be heavily advertised across campus and therefore their message and the meta-narrative that emerges from reading across these programs is consumed most widely. 


\section{Program Destinations: Imagined Geographies}

The first element of analysis involves how each institution divides up the regions of the world. To be clear, this is not a 'best practice' policy analysis. I do not seek to value one way of organizing programs over another or make any type of commentary on the utility of these organizations, but rather look at how the practice of ordering programs in a particular way may have discursive functions. For many of us, these divisions appear as what Antonio Gramsci (1971) would call 'common sense', or collective beliefs and assumptions that arise in a given society, which Gramsci argues are actually the remnants of former philosophies that through hegemony have become understood as making 'good sense'. However, he argues that this blind acceptance of the status quo leaves necessary alternative views of reality unquestioned.

Every study abroad office does this a little differently, as illustrated by the three institutions that this paper examines. The first, SEU, organizes their programs by countries and then by the following regions which are listed on their search engine site in alphabetical order: Africa, Asia, Australia/Pacific Islands, Europe, Latin America \& the Caribbean, Middle East, 'Multiple' (implying the program takes place in a number of these regions) and North America. NEU also organizes their programs by country and then by slightly broader regions listed in alphabetical order: Africa, Asia, Europe, Latin America and the Middle East. The MAU does not group their programs into regions at all but rather lists them by country in alphabetical order.

While administratively, logistically, and aesthetically, grouping programs by country and/or by region makes 'good sense' in doing so national geography is privileged over other program variables, like academic subject or instructor, again keeping in mind that program length is constant across these programs (short term, $<8$ weeks). The countries that are included in or excluded from a particular regional category also tell a story. For example, as can be seen in the tables to follow, NEU categorizes a program that takes place in Istanbul, Turkey under the 'Middle East' heading, while SEU categories their Istanbul program under the 'Europe' heading. Similarly, we find that SEU advertises two Moroccan programs, one of which is housed in their 'Africa' group and the other in their 'Middle East' group. Russia is given a 'Europe' categorization by SEU and an 'Asia' categorization by NEU. What do these inconsistencies imply? What are they 'teaching' students? What does the difference in categorizations of the same country imply, and does it influence students' expectations of Istanbul as a place, for example? How do the images, ideas, and preconceptions that are aroused by the 'European' Istanbul differ from that of the 'Middle Eastern' Istanbul?

Likewise, SEU is the only one of the three to list a 'North America' category. In line with what Alexander and Mohanty (2010) describe as the "transnational as always elsewhere" this is not surprising. However, what is surprising is that under SEU's North American heading there is only one program - to Puerto Rico. Puerto Rico's status as an "unincorporated territory of the United States" (Goldstein, 2014) calls into question its 'abroad' designation in the first place. Is the offering of a study abroad program in Puerto Rico an act in legitimizing its sovereignty or an act of 'othering' which further complicates its already confusing U.S. affiliation? Perhaps more interesting still is that other North American nation states like Mexico and the Dominican Republic are not categorized under the North America heading but rather that of 'Latin America and the Caribbean'. How and why is Puerto Rico assigned North American status while other North American nations are not? 
These arbitrary geographical distinctions are illustrative of what Edward Said refers to as "imagined geographies". In Orientalism (1979) he suggests that, "It is perfectly possible to argue that some distinctive objects are made by the mind, and that these objects, while appearing to exist objectively, have only a fictional reality" (p. 54, emphasis added). Thinking about whose mind leads us to a more discursive reading of these distinctions. "For there is no doubt that imaginative geography and history help the mind to intensify its own sense of itself by dramatizing the distance and difference between what is close to it and what is far away" (p. 55). We see dramatization of distance operating in the case of Puerto Rico as 'North American' and the Dominican Republic as 'Latin American and/or Caribbean'. Of course, these distinctions and other distinctions wield power, as critical geographers Crampton and Krygier (2005) explain: "Maps are active; they actively construct knowledge, they exercise power and they can be a powerful means of promoting social change" (p. 15). However, they argue that 'everyday mapping', which I would suggest should include the categorization of study abroad programs by region, needs to be critiqued in order to not reinforce generalized hegemonic spatial understandings.

\section{Uneven Cartographies of Knowledge}

\section{Distribution of Programs by Region and Country}

So far this paper has sought to uncover two interconnected elements of the institutional study abroad narrative. The first, the international vision and mission, tells a familiar story that represents larger trends in neoliberal reforms, student consumer culture, and global citizenship education. The second, Institutional Study Abroad Portfolios (ISAPs) begin to uncover global education curriculum that hides in administrative structures and recruitment material. In continuing that exploration, I now turn to an analysis of how programs with particular disciplinary foci are distributed across geographic locations, what patterns emerge, and how these patterns create hierarchies of knowledge.

Alexander and Mohanty (2010) took on a similar project, which is the inspiration for this section header, mapping the genealogies of transnational feminism in the U.S. and Canada through an analysis of Women and Gender Studies course syllabi. They argue that "the cartographic rules of the academy necessarily produce insiders and outsiders in the geographies of knowledge production" (p. 28). This is never more apparent than with study abroad programs, yet we rarely question who are 'insiders' and 'outsiders' in the study abroad apparatus. While the focus on nontraditional study abroad destinations in recent years gives the impression of progress in this regard, it is important to look at and think about what kind of knowledge and experience is being 'sold' to the student consumer in different parts of the world and what this implies about what those destinations have to offer. A disciplinary geographical analysis of ISAPs can shed light on the politicization of knowledge and produce what Alexander and Mohanty call 'hierarchies of place'. As they ask in their study of the transnational in feminist studies, I too ask "Who is constituted as knowledgeable and what type of knowledge is legitimized and discounted" within study abroad discourse?

We can begin simply by looking at the overall geographical distribution of programs, categorized below as they are by each institution. These are a combination of faculty-led programs that are usually designed, managed, and implemented 'in-house' as well as 'pre-approved third party provider programs'. I had originally wanted to look only at the former, as I think that these programs usually are most broadly supported and advertised on campus due to their strong institutional affiliation. However, I found that SEU and MAU only offered twelve and six 
independent faculty-led programs each summer respectively, meaning they are relying heavily on third-party providers to provide summer study abroad programming for their students. While the politics involved in essentially 'out-sourcing' what the international mission and vision claims to be 'academically rigorous' programming has been debated elsewhere (Redden, 2007) and will not be a major part of this analysis, it deserves further research and attention. Instead, faculty-led programming and those programs that are listed as 'pre-approved' on each institutions website will be listed together below, with the number of programs that are listed as institutionally sponsored in parenthesis next to the total regional number in each column.

Table 1. South Eastern University | Study Abroad Program Offerings, Summer 2015.

\begin{tabular}{|c|c|c|c|}
\hline \multicolumn{4}{|c|}{$\begin{array}{l}\text { South Eastern University } \\
\text { (Total Number of Summer }=294 \text {, Independent Faculty Led Programs }=12 \text { ) }\end{array}$} \\
\hline Region & Number of Programs & $\begin{array}{l}\text { \% of } \\
\text { ISAP }\end{array}$ & Countries Represented \\
\hline Africa & 7 (none are faculty-led) & $2.5 \%$ & $\begin{array}{l}\text { Botswana (1), Ghana (1), Morocco (1), Senegal (1), } \\
\text { South Africa (3) }\end{array}$ \\
\hline Asia & 40 (4 are faculty led) & $13.6 \%$ & $\begin{array}{l}\text { Cambodia (1), China (18), India (1), Japan (9), South } \\
\text { Korea (9), Thailand (1), Vietnam (1) }\end{array}$ \\
\hline $\begin{array}{l}\text { Australia/ } \\
\text { Pacific Island }\end{array}$ & 17 (none are faculty led) & $5.7 \%$ & Australia (12), New Zealand (5) \\
\hline Europe & 177 (4 are faculty led) & $60.2 \%$ & $\begin{array}{l}\text { Austria (1), Belgium (2), Czech Republic (9), France } \\
\text { (28), Germany (6), Greece (1), Ireland (15), Italy } \\
\text { (21), Netherlands (3), Poland (1), Portugal (1), Russia } \\
\text { (1), Spain (57), Turkey (1), United Kingdom (20) }\end{array}$ \\
\hline $\begin{array}{l}\text { Latin America } \\
\text { and the } \\
\text { Caribbean }\end{array}$ & 48 ( 4 are faculty led) & $16.3 \%$ & $\begin{array}{l}\text { Argentina (8), Brazil (9), Chile (5), Cost Rica (16), Cuba } \\
\text { (1), Dominican Republic (2), Grenada (1), Mexico (3), } \\
\text { Netherland Antilles (1), Peru (2) }\end{array}$ \\
\hline Middle East & 4 (none are faculty led) & $1.4 \%$ & Jordan (2), Morocco (1), United Arab Emirates (1) \\
\hline North America & 1 (none are faculty led) & $0.3 \%$ & Puerto Rico (1) \\
\hline
\end{tabular}

Table 2. New England University | Study Abroad Program Offerings, Summer 2015.

\begin{tabular}{|l|l|l|l|}
\hline \multicolumn{4}{|l|}{$\begin{array}{l}\text { New England University } \\
\text { (Total Number of Summer= 35, Independent Faculty Led Programs = 29) }\end{array}$} \\
\hline Region & Number of Programs & $\%$ of ISAP & Countries Represented \\
\hline Africa & 1 (it is faculty-led) & $2.9 \%$ & Zambia (1) \\
\hline Asia & 3 (all are faculty led) & $8.6 \%$ & India (1), Indonesia (1), Vietnam (1) \\
\hline Europe & 27 (21 are faculty led) & $77.1 \%$ & $\begin{array}{l}\text { Denmark (1), France (5), Germany (1), Ireland (4), } \\
\text { Italy (7), Spain (4), Turkey (1), England (2) }\end{array}$ \\
\hline
\end{tabular}




\begin{tabular}{|l|l|l|l|}
\hline Latin America & 3 (all are faculty led) & $8.6 \%$ & Ecuador (2), Chile (1) \\
\hline Middle East & 1 (it is faculty led) & $2.9 \%$ & Kuwait (1) \\
\hline
\end{tabular}

Table 3. Mid-Atlantic University | Study Abroad Program Offerings, Summer 2015.

\begin{tabular}{|l|l|l|l|}
\hline $\begin{array}{l}\text { Mid Atlantic University } \\
\text { (Total Number of Summer= 15, Independent Faculty Led Programs =?) }\end{array}$ \\
\hline $\begin{array}{l}\text { Approx. } \\
\text { Region* }\end{array}$ & Number of Programs & $\%$ of ISAP & Countries Represented \\
\hline Africa & 1 & $6.7 \%$ & South Africa (1) \\
\hline Asia & 2 & $13.3 \%$ & Japan and Taiwan (1), Russia (1) \\
\hline Europe & 8 & $53.3 \%$ & $\begin{array}{l}\text { Denmark (1), England (2), France (1), Germany (1), Ireland } \\
(1), \text { Netherlands (1), Scotland (1) }\end{array}$ \\
\hline $\begin{array}{l}\text { Latin } \\
\text { America }\end{array}$ & 3 & $20 \%$ & Cuba (1), Ecuador (1), Peru (1) \\
\hline Middle East & 1 & $6.7 \%$ & Israel (1) \\
\hline
\end{tabular}

*as stated above MAU does NOT list their programs by Region on their site - it has been done here only for comparative purposes, it is not immediately apparent on their site which programs, if any, are faculty-led

Figure 1. Regional Program Distribution Across All Three Institutions.

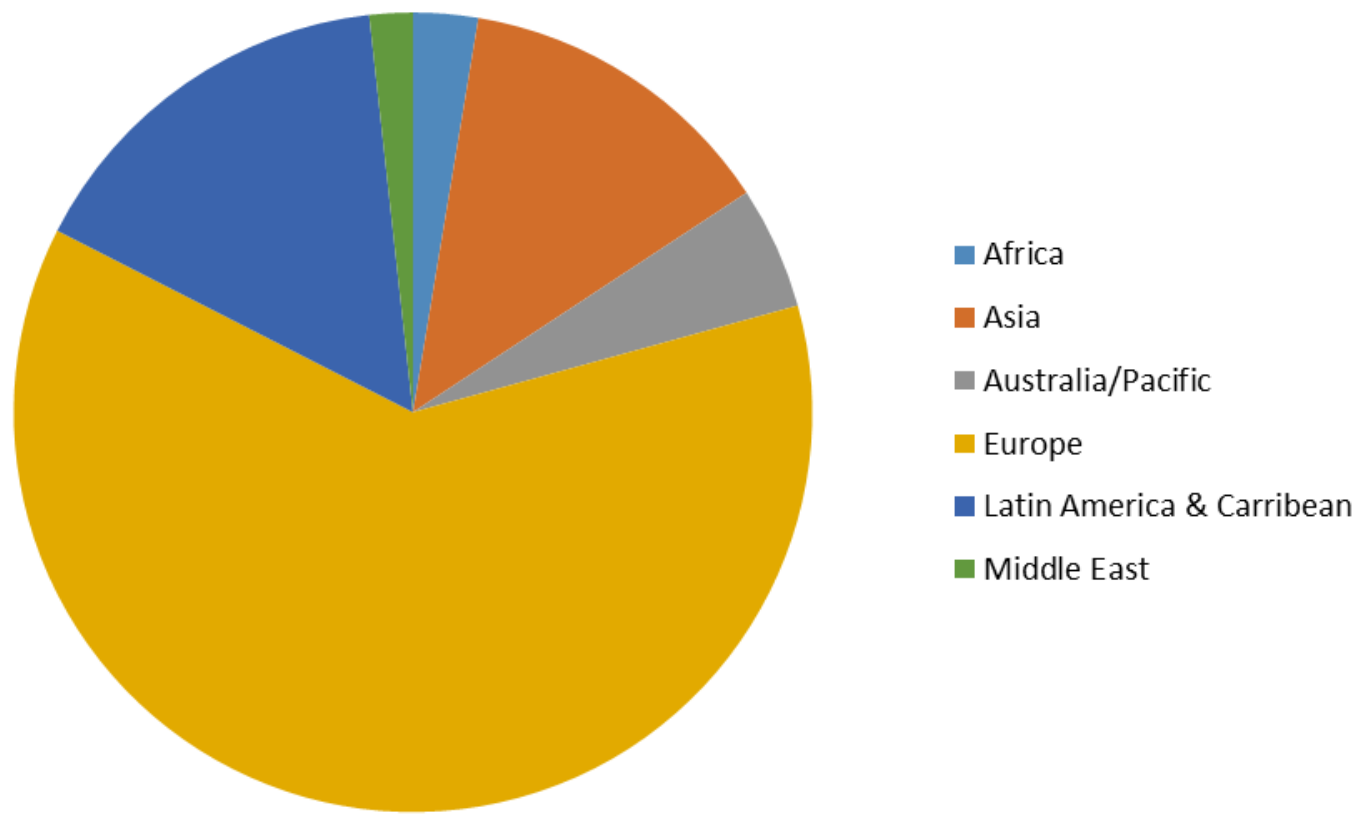

We see that across all three institutions European programming accounts for an average of 63\% of ISAP, with African programs, in contrast, accounting for an average of $4 \%$ of ISAP. How are these distributions alone serving to legitimize and delegitimize certain origins of knowledge production? What political and historical commitments do these distributions suggest and are they more strongly reflective of national interests or independent intellectual inquiry? When students, even (and especially) those who will never study abroad, visit a study abroad website, inspired by their institutions' charge to 'become a global citizen', what do they learn about where and with whom one becomes 'global'? Are they inspired to question Eurocentric notions of the world order, 
or are those sentiments further reinforced through the program distributions listed above? The next investigation of where students can go to engage with which particularly types of disciplinary knowledge will further reinforce some of these ideas.

\section{Distribution of Programs by Region and Discipline}

The data in Figure 2 represents the combined Summer 2015 study abroad offerings across all three institutions (SEU, NEU and MAU). Each of the 344 programs was coded by the regional categorization given to it by the offering institution, or in the case of MAU programs, was assigned a region based on the broadest categories, used by SEU. Each program was then coded by its disciplinary or 'functional' (in the case of work, internship or service learning) offering, as illustrated by the program title only. The idea here was to simulate the experience of an interested but uncommitted student casually browsing program offerings, as again, I am trying to capture the hidden learning that takes place not only by those students who are committed to studying abroad and actually take part in a program, but also those students and university community members who do not end up actually participating on a program.

Figure 2. SEU, NEU and MAU Combined ISAPs by Region and Discipline.

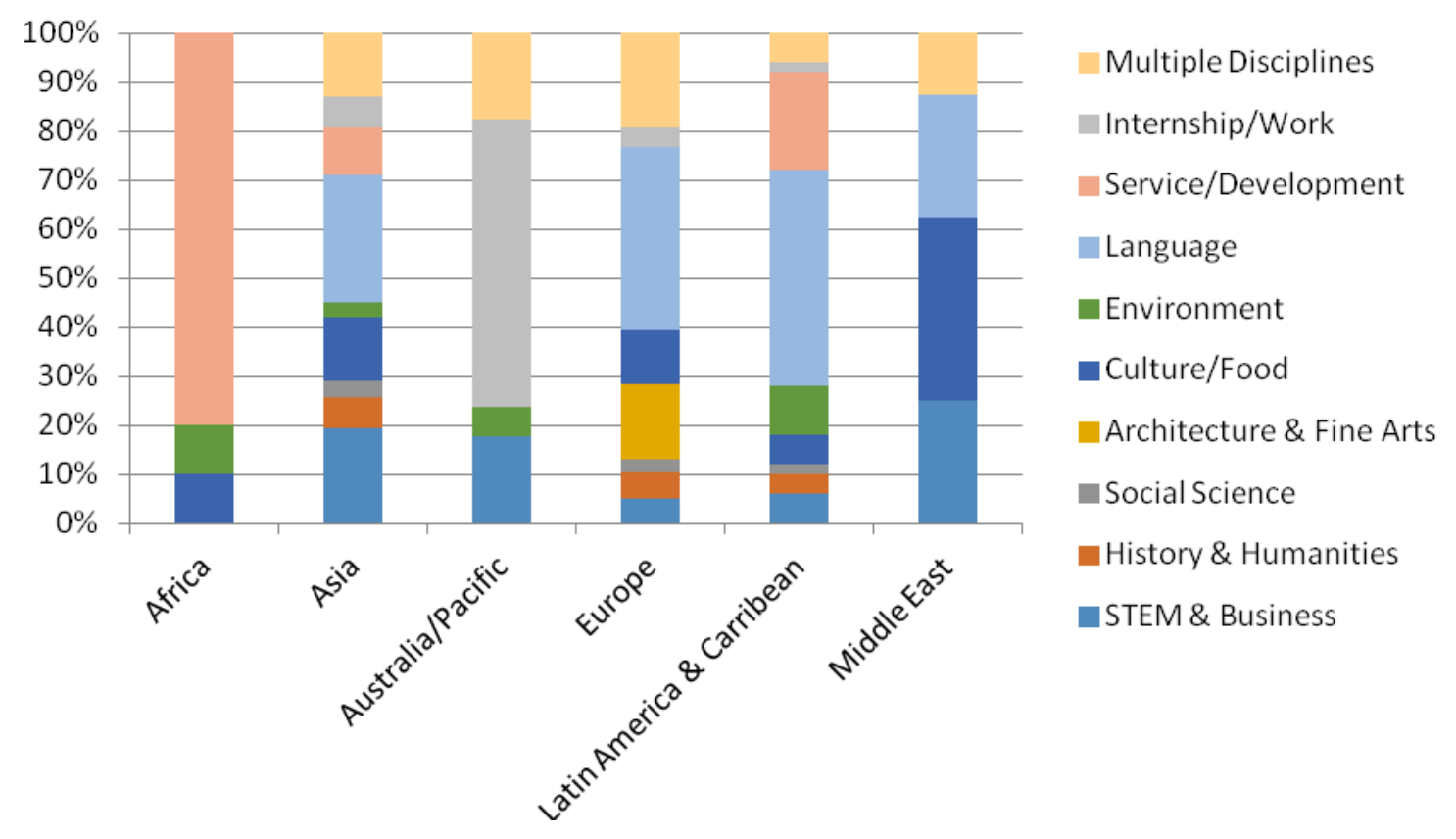

\section{Africa \& Latin America: 'help!'}

The themes that emerge around the types of disciplinary knowledges that are legitimized in particular national contexts through this combined ISAP are extremely troubling. Using ISAP as a representation of study abroad discourse by region we see that Africa is represented by only three 'disciplines' - the most prominent of which (a staggering 80\%) is service learning or development. This is problematic in a number of ways. One way is that it reinforces media driven stereotypes of the African continent as in need of help, specifically, white, Western help. Another way is what is left out of study abroad in Africa discourse when programs are so heavily service learning focused. 
The point is not to make a case against or even a value judgment on service learning or 'development' work. The danger lies in that these efforts are disproportionally directed towards Africa(ns). The story that this tells the would-be study abroad participant is that what Africa has to offer to you as a student, is poor, 'underdeveloped' people to 'help' at best and 'save' at worst. This trend is no doubt related to the rise of 'celebrity humanitarianism' culture, which Mostafanezhad (2013) writes about in her brilliantly titled article 'Getting in Touch with Your Inner Angelina: Celebrity bumanitarianism and the cultural politics of gendered generosity in volunteer tourism' in which she describes the rise in white females going abroad and modeling their behavior, or social media representations thereof, around images of celebrities like Madonna and Angelina Jolie.

What is implied by such a strong focus on service learning in Africa is that that language, architecture, art, business, STEM (science, technology, engineering and math), and by extension African universities themselves, either do not exist on the continent or at least not in a way that should be privileged by/through study abroad. As Said notes in his discussion of Imagined Geographies in Orientalism: "cultures have always been inclined to impose complete transformations on other cultures, receiving these other cultures not as they are but as for the benefit of the receiver, they ought to be" (p. 67). How must U.S. students coming to Africa, almost exclusively to partake in service learning, impact the intellectual subjectivity of African scholars and institutions?

Likewise in Latin America, a strong service learning focus is present but with the added Spanish language component. Much like Africa, an 'environmental' focus comes second. Why are Latin America and Africa connected in this way disciplinarily? Could it be their colonial 'pasts', or the color of the populations? What do these enormous and imagined geographies have in common that imply that certain types of knowledge are and are not present there? Why is language such an integral part of many service learning programs in Latin America but not in Africa? This calls into question the actual commitments and intentions of service learning and supports the ideal of service 'self development' (Cook, 2012).

\section{Asia \& the Middle East: Doing business with the 'Other'}

We see that Middle Eastern programming also lacks broad disciplinary distribution with the foci of Food/Culture, Business, and Language making up over $85 \%$ of program offerings. All business programs but one in the Middle East are focused on Oil and Trade. This could be understood in a number of ways, one being: as an avenue for U.S. students to genuinely learn from the expertise of people in a place that 'does oil business' better than we do in the U.S., or of course, to further reinforce stereotypes of the 'Middle Eastern oil tycoon'. The goals and methodologies of each of these programs can certainly not be gleaned from an elementary analysis of their program title, however, a business program in the Middle East focused on oil is predictable, much like a service learning program at an orphanage in Africa. The point is not to deny that oil is big business in some parts of the Middle East or that there are orphanages in Africa, but it is the programs that do not exist in these places that tell the more problematic and compelling story.

\section{Australia/Pacific: Intern}

Australia and New Zealand are overwhelming defined by internship programs. Admittedly, this is likely due in large part to a popular third-party provider organization that focuses specifically on internship placements in this part of the world. However, other than Europe, Australia and New Zealand were the only regions of the world where internships were on offer. The availability of 
internships at many multi-national organizations could be read as a sign of this region's 'modernity' and Western '-ness'. How different are these internship experiences than those service learning experiences offered in Africa and Latin America? How do the semantics function in ways that portray work in different ways across these contexts?

\section{Europe: Where Art Lives \& Anything is possible}

One of the stories that speak the loudest through this analysis is the variety in programming on offer across Europe. Almost every discipline can be found in a program offered in Europe - except, tellingly, service learning. Europe was also the only region in the analysis that offered a program that is dedicated solely to the study of the Fine Arts or Architecture. In this ISAP reading, Europe is placed in the middle of the world, and has literally everything to offer the U.S. student. Europe also had the most 'multiple discipline' programs, meaning in most cases programs housed at an actual foreign university, so students would have access to any course offered there over the summer. This program model was rare outside of Europe, occurring less than $20 \%$ of the time in all other regions (with the exception of Africa where no 'multiple discipline' programs where offered).

\section{Future Directions}

While this paper is by no means a conclusive project, it has sought to complicate the ways that we think about how and where global learning takes place within U.S. universities and specifically how Institutional Study Abroad Portfolios (ISAPs) can be used as a site for discourse analysis. My hope is that it will begin to shape new ways of thinking about mid-level (between institutional and programmatic) analyses and the apparent disconnect between the rhetoric of international mission and vision statements and the ways they are taken up.

Firstly, we need to think about the utility of mission and vision statements as 'agenda setters' in International Education and their lack of criticality. Secondly, there needs to be more research that connects theory to practice in the realm of internationalization of higher education in general. There is a great deal of promise in making theoretical connections to the nuts and bolts work of study abroad programming, and too often theorists and mid-level professionals are not brought into dialogue with one another or the later are not encouraged to create their own theory. Finally, there is much to do and think about in regards to the regional disproportionality of different disciplinary study abroad programs.

What makes much of this work particularly challenging is that so many institutions across the U.S., North America, and the world are in such different phases of internationalization. While some institutions struggle to convince leadership that students should engage with international perspectives at all and therefore struggle to produce any study abroad programs, others have massive internationalization apparatuses and send thousands of students overseas every year. Yet, the call here is for all institutions to take a critical look at what 'imagined geographies' are represented or perpetuated through their global programming, whichever form it currently takes, and to take seriously the responsibility that comes along with educating students about the world. This begins with a critical recognition of the ways in which programs are advertised and different regions of the world are represented, and grows by understanding that institutions actively partake in the legitimation and delegitimation of certain types of knowledges through their ISAPs. 


\section{References}

Alexander, J. \& Mohanty, C. T. (2010). Cartographies of Knowledge and Power: Transnational Feminism as Radical Praxis. Critical Transnational Feminist Praxis (Eds.) Amanda Lock Swarr and Richa Nagar. (23-45) Albany, NY: SUNY Albany Press.

American Council on Education (2008). College-Bound Students' Interests in Study Abroad and Other International Learning Activities. Accessed: http://www.acenet.edu/news-room/Documents/2008Student-Poll.pdf

Apple, M. W. (1982). Education and Power. Boston: Routledge.

Bishop, S. C. (2013). The Rhetoric of Study Abroad: Perpetuating Expectations and Results Through Technological Enframing. Journal of Studies in International Education, 17, 398-413.

Bolen, M. (2001). Consumerism and U.S. Study Abroad. Journal of Studies in International Education, 5, 182-200.

Brockington, J., Hoffa, W., \& Martin, P. (2005). (Eds.), NAFSA's Guide to Education Abroad for Advisers and Administrators (3rd ed.) (445-478). Washington, DC: NAFSA: Association of International Educators.

Cabrera, L. (2010). The practice of global citizenship. Cambridge: Cambridge University Press.

Caton, K., \& Santos, C. A. (2009). Images of the Other: Selling Study Abroad in a Postcolonial World. Journal of Travel Research, 48(2), 191-204.

Childress, L. K. (2009). Planning for internationalization by investing in faculty. Journal of International and Global Studies, 1(1), 30-49.

Clarke, V. (2004). Students' global awareness and attitudes to internationalism in a world of cultural convergence. Journal of Research in International Education, 3(1), 57-70.

Cook, N. (2012). I'm here to help: Development Workers, the Politics of Benevolence and Critical Literacy. In Postcolonial Perspectives on Global Education (Eds.) V. Andreotti and L. M. T. M. de Sousa (124-139) New York: Routledge.

Crampton, J. W., \& Kryger, J. (2005). An Introduction to Critical Geography. ACME: An International Journal for Critical Geographies, 4(1), 11-33.

Crossman, J. E. \& Clarke, M. (2009). International experience and graduate employability: stakeholder perceptions on the connection. Higher Education, 59(5), 599-613.

Giroux, H. (1983). Theories of Reproduction and Resistance in the New Sociology of Education: A Critical Analysis. Harvard Education Review, 53, 257-293.

Goldstein, A. (2014). Toward a Genealogy of the U.S. Colonial Present. In Introduction to Formations of United States Colonialism (Ed.) A. Goldstein (1-33). Durham, NC: Duke University Press.

Gramsci, A. (1971). Selections from the Prison Notebooks. New York: International Publishers.

Institute of International Education. (2013).Open Doors Report on International Educational Exchange. Retrieved from http://www.iie.org/opendoors.

Knight, J. (2004) Internationalization Remodeled: Definition, Approaches, and Rationales. Journal of Studies in International Education, 8(1), 5-31.

Lyotard, J.-F. (1984). The Postmodern Condition: A Report on Knowledge. Minneapolis: University of Minnesota Press.

Martin, J. (1984) What Should We Do with a Hidden Curriculum When We Find One? In The Hidden Curriculum and Moral Education (Eds.) Henry Giroux and David Purpel (122-139). Berkeley, CA: McCutchan Publishing Corporation,

Mama, A. (2007). Is It Ethical to Study Africa? Preliminary Thoughts on Scholarship and Freedom. African Studies Review 50(1), 1-26.

Milstein, T. (2005). Transformation aboard: Sojourning and the perceived enhancement of self-efficacy. International Journal of Intercultural Relations, 29(2), 217-238.

Mitchell, P. (2006). Revisiting effective re-entry programs for returnees from US academic programs. Washington, DC: NAFSA Association of International Educators. Retrieved from: http://www.nafsa.org/resourcelibrary/default.aspx?id=8888 
Morphew, C., \& Hartley, M. (2006). Mission Statements: A Thematic Analysis of Rhetoric Across International Type. Journal of Higher Education, 77(3), 456-471.

Mostafanezhad, M. (2013). 'Getting in Touch with your Inner Angelina': Celebrity humanitarianism and the cultural politics of gendered generosity in volunteer tourism. Third World Quarterly, 34(3), 485499.

Redden, E. (August 20, 2007). Intermediaries in Study Abroad. Inside Higher Education. Retrieved November 21, 2014,http://www.insidehighered.com/news/2007/08/20/abroad\#Comments

Said, E. (1979) Orientalism. New York: Vintage.

Stephens, J., \& McCallum, R. (2013). Retelling stories, framing culture: traditional story and metanarratives in children's literature. New York: Routledge.

Taylor, L. (2011). Beyond paternalism: Global education with preservice teachers as a practice of implication. In Postcolonial perspectives on global citizenship education. (Eds.) V. Andreotti \& M. Souza (177-199). New York: Routledge.

Tikly, L. (2004). Education and the new imperialism. Comparative Education, 40(2), 173-198.

Wa Thiango, N. (1986). Decolonizing the Mind: The Politics of Language in African Literature. New York: Twayne Publishers.

Zemach-Bersin, T. (2008). Selling the World: Study Abroad Marketing and the Privatization of Global Citizenship. In The Handbook of Practice and Research in Study Abroad: Higher Education and the Quest for Global Citizenship (Ed.) Ross Lewin. (303-320) New York: Routledge. 